\title{
Lou Salomé - A mulher a quem Nietzsche amou*
}

\author{
A. de Monzie**
}

Resumo: Partindo de uma referência inicial à tese que nomeia um de seus livros (As viúvas abusivas, 1937), o autor busca explorar o caráter de Lou-Andreas Salomé a partir da obra que ela publicou sobre Nietzsche. A “interpretação testamentária” de Lou sobre a personalidade do filósofo alemão em 1893 revelaria não a Nietzsche, mas a psicologia de uma "coquete estudiosa", uma "sereia calculista", cujo "cinismo frio" seria, no mínimo, odioso.

Palavras-chave: Nietzsche - Lou Salomé - biografia - psicologia - cinismo.

Na galeria das viúvas abusivas, devem também figurar outras espécies de mulheres, que tiram vantagens da morte dos homens: memorialistas excessivas, vampiros elegíacos, musas de túmulos, cujo lamento se modula em ritmo de dança, concubinas distintas, que se cobrem de luto para subir de grau, novelistas apressadas em divulgar os falsos segredos de seus falsos amantes mortos, e outras mais, que parecem evocar os espectros ilustres, para melhor realçar a presença dos vivos.

Certos casos revoltam pelo cinismo frio de que se revestem. Entre esses, conta-se o de Mme. Lou Andreas Salomé, caso singular e que permanece litigioso. Essa criatura inteligente e ambiciosa teve a habilidade de se apropriar de Nietzsche sem para isso fazer dispêndios de coração.

Os detalhes da aventura que entregou o filósofo a Lou Salomé são desses que merecem ser relembrados, porque nos deixaram um

\footnotetext{
* Publicado no Correio da Manhã. Rio de Janeiro, Sábado, 18 de Julho de 1942, p. 9.

** Anatole de Monzie (1876-1947). Advogado, político e escritor francês. Autor de Petit manuel de la Russie nouvelle (1931) e Les Veuves abusivez (1937).
} 
triste ensinamento.

Nietzsche amou-a e pretendeu desposá-la. Ela recusou - era seu direito. Ele sofreu - era seu destino. Conheceram-se em 1882 o professor Frederico Nietzsche tinha então trinta e oito anos e era feito, a estudante eslava Lou Salomé tinha apenas vinte e era bonita.

Asfixiado de solidão e sem discípulos a quem confessar seu gênio, Nietzsche, um belo dia, encontrou Lou Salomé, rapariga de ciência, que devia fazer carreira, indo de Paul Rée a Sigmund Freud - da psicologia inglesa à psicanálise vienense - mas, que pelo caminho arrastou Nietzsche e depois atraiu J. Maria Rilke. Não se poderá dizer dela que fosse um anjo de rapina, pois dissecava meticulosamente, em vez de dilacerar.

Em 1893 Lou Salomé publicou um livro intitulado: "Ensaio sobre a caracterização de Nietzsche", trabalho que lhe confere uma prioridade nietzschiana. Ora, nessa data, Nietzsche está louco, internado numa casa de saúde; é quase um morto e, por isso, a obra apresenta-se com a aparência de uma interpretação testamentária, graças à narrativa daquele amor furtivo.

O Ensaio, que, aliás, nada tinha de um esboço, resume em forma crítica, com minúcias de cuidado e de escrúpulo, os episódios românticos de 1882 .

Uma recente tradução francesa permite facilmente reconstruir a gênese patética daquela publicação.

Lou Salomé tinha uma maneira deliciosa de ouvir e enquanto Nietzsche enlevado em vê-la atenta, tomava esperança, ela tomava notas: enquanto ele meditava um amor, ela premeditava uma tese...

Essa manobra de coquete estudiosa era-lhe habitual ela sabia usar de sedução para tirar de suas lições particulares o máximo lucro. Já em Helsingfors, conseguira enfeitiçar um de seus mestres, homem pacato, atado de deveres de família, de quem ela utilizou os escrúpulos às necessidades ulteriores de uma documentação romântica. Para Lou Salomé, o flerte tornava-se um método de laboratório. 
Monzie, A.

Depois do mestre de Helsingfors, encontrou Nietzsche.

A princípio, a inteligência brilhante e a extraordinária compreensão da discípula maravilharam o professor; aos poucos, sob o doce efeito da primavera romana, um sentimento de ternura foi se substituindo a essa admiração. Depois, a jovem eslava já dedicava ao poeta-filósofo poemas que o perturbavam, oferenda de palavras enganosas, de efusões sem objeto, mas não sem efeito.

Como poderia o pobre Lélian da metafísica resistir à miragem daquela alma atenta e atenciosa? Quando, mais tarde, descobriu seu erro, Nietzsche exclama: “o mal que me fizeste é pior que um assassinato - tirou-me o insubstituível". O insubstituível era o senso inédito que ele emprestava à existência daquele amor humano, demasiada e dolorosamente humano!

Ela, no entanto, prossegue em seu programa de acumular tesouros literários, sem se emocionar com os estremecimentos da carne viva, friamente retalhada por suas investigações psicológicas.

Mais tarde, estabelecendo um paralelo entre Nietzsche e Paul Rée, seu amigo, Lou Salomé enaltece a superioridade deste último, que sabia "separar seus pensamentos de suas emoções", enquanto Nietzsche era "vítima da dependência de emoções intensas e dos impulsos de sua alma". "Em Paul Rée, o pensador contempla de muito alto o homem!". E, sem dúvida, de mais alto ainda a mulher, razão pela qual assumia proporções gigantescas de intelectual másculo, diante daquela estudante incapaz ou indigna de compreender a formidável genuflexão de um Nietzsche!

Satisfeitas suas pesquisas eruditas, ela afasta-se do filósofo aguardando pacientemente a hora propícia de uma entrada em cena, a hora oportuna para colocar Nietzsche "en devanture".

Em 1882 e 1893, onze anos de espera - espera longa, mas que se anuncia lucrativa. A loucura de Nietzsche garante uma dupla vantagem: de segurança e de publicidade.

Debalde a irmã deste, Mme. Forster-Nietzsche protesta contra aquele embuste, hoje absolvido por um caridoso ceticismo. 
"Cinquenta anos são passados; serenaram os ódios pessoais; esse episódio da vida de Nietzsche pertence à História”. À História também pertence Lou Salomé, cujo nome se inscreve nos anexosbiográficos e bibliográficos de uma legenda negra.

E quanto aos festejos organizados em 1893, em Weimar, em homenagem a Goethe, convites especiais foram enviados à descendência, à parentela, à família espiritual dos escritores "faustianos". Mme. Lou Salomé teve uma poltrona ao lado da irmã de Nietzsche, que se insurgiu contra aquela vizinhança oficial.

$\mathrm{O}$ amor do homem cria para a mulher que ama ou mesmo que não ama, obrigações e não prerrogativas. Antes de tudo, obrigações de mutismo!

Lou Salomé, sereia calculista, cuja perfeição adstringente causou maior dano do que uma traição, é a noiva que depois de desfeito o compromisso, guarda as joias do noivado para com elas se enfeitar mais tarde, muito mais tarde, em exibições futuras. E por isso, apesar de irrepreensível, no sentido exato da palavra, não é menos odiosa.

\begin{abstract}
From a first reference up to the thesis that names one of her books (The Abusive Widows, 1937), the author explores Lou-Andreas Salomé's character from the work on Nietzsche published by her. Lou's "testamentary interpretation" of the German philosopher's personality in 1893 would reveal not Nietzsche, but the psychology of a "scholarly coquette," a "calculating siren," whose "cold cynicism" would be at least odious.
\end{abstract}

Keywords: Nietzsche - Lou Salomé - biography - psychology - cynicism. 